\title{
Dietary Exposure to Mercury of the Adult Population in Mugusu Artisanal Gold Mining Village, Tanzania: A Total Diet Approach
}

\author{
C. Tungaraza ${ }^{1 *}$ R.T. Chibunda ${ }^{2}$, and A.E. Pereka ${ }^{2}$ \\ ${ }^{I}$ Department of Physical Sciences, Faculty of Science, Sokoine University of Agriculture, P.O. Box 3038, Chuo Kikuu, \\ Morogoro, Tanzania \\ ${ }^{2}$ Department of Veterinary Physiology, Biochemistry, Pharmacology and Toxicology, Sokoine University of Agriculture, \\ P.O. Box 3017, Chuo Kikuu, Morogoro, Tanzania
}

\begin{abstract}
Gold extraction by artisan miners in different parts of Tanzania is widely done by mercury amalgamation technique. To the people living in and around the mining cites there is a potential for exposure to contamination through consumption of $\mathrm{Hg}$ contaminated food stuffs. Current studies on estimates of dietary human exposure to mercury in these areas have been limited to contributions of $\mathrm{Hg}$ contaminated fish consumption centrally to WHO recommendation on the use of Total Diet Studies. In this study dietary Hg intake of people at Mugusu gold mining village was determined by using a total diet study approach. Results indicate that 37 types of foods are consumed in this Village. Rice, maize, tubers and fish were the most consumed food categories with an average daily consumption of 134, 270, 113 and $97 \mathrm{~g}$ per person per day, respectively. The fish category contained the highest average content of total $\mathrm{Hg}\left(0.16 \mu \mathrm{g} \mathrm{g}^{-1}\right.$ wet weight). The calculated average dietary intake of $\mathrm{Hg}$ was $41.05 \mu \mathrm{g} / \mathrm{day}$, which is 2.6 times higher than the daily intake recommended by FAO/WHO $(15.5 \mu \mathrm{g} / \mathrm{day})$ for protection of the foetus and young children. It is therefore concluded that the current total dietary intake of $\mathrm{Hg}$ in the studied area is at risk level to young children born to women living in this village. It is therefore recommended that, mercury intake in artisanal gold mining settlements should be monitored regularly.
\end{abstract}

Key Words: Exposure, mercury, gold mining, Tanzania.

\section{INTRODUCTION}

Many reports have been published on environmental $\mathrm{Hg}$ contamination associated with the artisanal gold mining in Tanzania. These reports have mainly been on the build up of mercury in soils, sediments, fish, pastures and some root crops [1-3]. The major concern of such studies should target people living in areas under gold mining activities which are subjected to direct exposure (i.e. persons handling $\mathrm{Hg}$ ) and indirect exposure through consumption of $\mathrm{Hg}$ contaminated food stuffs. Until now studies that have been conducted to estimate exposure of humans to mercury in artisanal gold mining areas in Tanzania have been confined to examining exposure through fish consumption [4]. The World Health Organisation (WHO), however, recommends the use of Total Diet Studies (TDS) to assess total Hg intake. The TDS approach has the advantage of yielding more refined exposure data since it consists of analysing a representative 'market basket' of foods. This methodology takes into account of the effects of kitchen preparation on the levels of contaminants in foods [5-7] The food products are bought or collected from the normal retail channels and prepared as if for consumptions: edible parts from different food stuffs are ana-

*Address correspondence to this author at the Faculty of Science, Sokoine University of Agriculture, P.O Box 3038, Morogoro, Tanzania; Tel: $+255-$ 23-2603404; Fax: +255-23-2603404; E-mails: tungarazac@yahoo.co.uk, tungaraza@suanet.ac.tz lysed for the contaminant of interest (Hg-in this study). The combination of the metal concentrations measured in the food products analysed and the consumption information, permits estimation of dietary exposure. The objective of the present study was to assess the dietary mercury intake by the people living at Mugusu artisanal gold mining village using the TDS approach. This provides extra sources of contaminant uptake than using a single food type.

\section{MATERIALS AND METHODS}

\section{Total Diet Study}

To evaluate the health risk, the estimated dietary daily $\mathrm{Hg}$ intake was compared with the Provisional Tolerable Intake recommended by the joint FAO/WHO Expert Committee for Food Additives (JECFA) for Hg for the protection of the general public $(49 \mu \mathrm{g} / \mathrm{day})$ and that for the protection of developing foetus $(15.5 \mu \mathrm{g} /$ day) [8]. A 24 hours recall food survey was carried out with a representative sample $(\mathrm{n}=$ 207) of the adult population whose characteristics are indicated in Table $\mathbf{1}$. The survey was done for two working days and one weekend towards the end of the dry season in the month of September, 2007. All participants were visited at home and a food frequency and amount questionnaire combined with household containers of different sizes was used to estimate intake. The 24 hours recall indicated consumption of up to 37 food items, which were grouped into 11 food categories according to similarity in chemical composition. 
Table 1. Demographic Characteristics of Respondents at Mugusu artisanal Gold Mining Village

\begin{tabular}{|l|c|}
\hline Variable & Number (\%) \\
\hline \hline sex & \\
\hline Male & $135(65)$ \\
\hline Female & $72(35)$ \\
\hline Age category & $17(8)$ \\
\hline $18-22$ & $46(22.3)$ \\
\hline $23-30$ & $91(44)$ \\
\hline $31-45$ & $53(25.7)$ \\
\hline$>45$ & $22(10.6)$ \\
\hline Education & $154(74.4)$ \\
\hline No formal education & $31(15)$ \\
\hline Primary education & \\
\hline Secondary education & \\
\hline
\end{tabular}

contamination in these blanks. Analytical quality control was ensured through the analysis of certified reference material DORM-2 (Dogfish muscle) from the National Research Counsel Canada $\left(4.64 \pm 0.26 \mu \mathrm{g} \mathrm{g}^{-1}\right.$ certified level of mercury) and analysis of mercury standards. All data were computed on a $\mu \mathrm{g} \mathrm{g}^{-1}$ wet weight basis.

\section{Estimation of Dietary Exposure to Mercury}

Dietary exposure to mercury from an individual food category was determined by multiplying the concentration of mercury in the food by its intake. Dietary exposures from individual food categories were expressed on a body weight basis by dividing the total dietary exposure by the average body weight $(55 \mathrm{~kg})$ of the population [9], which in this study was established from the average weight of $60 \%$ of our study population (125).

Samples below the Level of Detection (LOD) $(0.02 \mu \mathrm{g} / \mathrm{g})$ were assigned half value of LOD $(0.01 \mu \mathrm{g} / \mathrm{g})[10]$.

\section{RESULTS AND DISCUSSION}

Table 2 shows the list of food types, their respective quantity consumed (g/day) and mean $\mathrm{Hg}$ content. A total of

$$
\text { Daily intake of } \mathrm{Hg}(\mu \mathrm{g} / \mathrm{kg} \text { bwt/day })=\frac{\sum(\text { mean conc. of } \mathrm{Hg} \text { in each food category }(\mu \mathrm{g} / \mathrm{g}) \times \mathrm{mean} \text { food intake }(\mathrm{g} / \mathrm{person} / \mathrm{day}))}{\text { Average body weight }(55 \mathrm{~kg})}
$$

Food stuffs which were reported to be consumed in large quantities, e.g. maize and rice were considered as independent food categories. Food items in the established categories were purchased from different sellers at a local market and others were obtained free of charge from households in the surveyed area. Samples collected from different households/sellers were thoroughly mixed to make a homogeneous sample. The samples were individually packed in self zipping air tight bags and kept in a cooler box until prepared and cooked. The samples were subsequently prepared according to the most typical form of consumption (raw, washed and/or peeled). The most representative cooking method of boiling was employed. After cooking, the foods were allowed to cool, homogenized, aliquoted in $100 \mathrm{~g}$ amounts and stored frozen at $-20^{\circ} \mathrm{C}$ in nitric acid washed glass bottles until chemical analysis.

\section{Mercury Analysis}

Total mercury analysis was done at the chemical laboratory of Southern and Eastern Africa Mineral Centre (SEAMIC) in Dar es Salaam - Tanzania. Homogenized samples of $(1-2 \mathrm{~g} \mathrm{ww})$ were digested to a transparent solution with $15 \mathrm{ml}$ of the mixture $\mathrm{HNO}_{3}: \mathrm{H}_{2} \mathrm{SO}_{4}(1: 2)$ under reflux. The resultant solutions were then diluted to $20 \mathrm{ml}$ with deionised water and the total Hg concentrations were measured by atomic absorption spectrophotometer cold vapour generation technique (ICP Ultima 2, Horiba Jobin Yvon, France). Acid washed glassware, analytical grade reagents and deionised water were used in the tissue analysis. In order to check for the purity of the chemicals used, one chemical blank was run every 10 samples. There was no evidence of
37 food items were mentioned during the food survey. Rice, maize, tuber crops and fish were found to be the principal food categories in the study area. It is observed that water constitute the largely consumed food component ( $885 \mathrm{~g} /$ day) followed by maize (270 g/day) and tilapia (260 g/day). To this community it is important to note that among fish types, tilapia and sardines (176 g/day) are the major daily meal components than Nile perches (65 g/day) which have been greatly explored by other studies in relation to mercury contamination in the area. Apart from the quantitative assessment of the consumed food, analytical results provides that water (the most consumed food component) is one of those constituting the minimum mercury concentration $(<0.02 \mu \mathrm{g}$ $\mathrm{Hg} / \mathrm{g}$, below detection level). This trend was also observed with sardines but not with tilapia which ranked fourth in abundance providing $0.123 \mu \mathrm{g}-\mathrm{Hg} / \mathrm{g}$. It is observed that the Nile perches levels $(0.37 \mu \mathrm{g} / \mathrm{g})$ and catfish levels $(0.335$ $\mu \mathrm{g} / \mathrm{g})$ had the highest mercury concentration of all the consumed food stuff in the village.

The daily mercury intake from each food category listed in Table 3 indicate that highest mercury intake was from fish (15.6 $\mu \mathrm{g} /$ day) followed by water $(8.85 \mu \mathrm{g}$ /day) tuber crops (4.35 $\mu \mathrm{g} /$ day) and rice (4.0 $\mu \mathrm{g}$ /day). This is similarly reflected by the concentration of mercury in the food categories where the highest mercury concentrations were found in fish $\left(0.16 \mu \mathrm{g} \mathrm{g}^{-1}\right)$. Mercury concentration in fish is therefore three times and four times higher than that in vegetables and tuber crops, respectively. In the fish category, as displayed in Table 2, Nile perches contributed the highest $\mathrm{Hg}$ concentration $\left(0.37 \mu \mathrm{g} \mathrm{g}^{-1}\right)$. On average it was estimated that $\mathrm{Hg}$ intake per person was $41.05 \mu \mathrm{g} / \mathrm{day}$. 
Table 2. Food Types, Quantity Consumed and Hg Concentrations in Food Items Included in the total Diet Study Performed at the Mugusu Mining Village

\begin{tabular}{|c|c|c|c|}
\hline Category & Food Type & Consumption (g/day) & Hg Concentration $(\mu \mathrm{g} / \mathrm{g})$ \\
\hline Rice & Rice & 134.0 & 0.026 \\
\hline Maize & Maize & 270.0 & 0.022 \\
\hline \multirow[t]{3}{*}{ Other cereals } & Bulrush Millet & 23.0 & $<0.020$ \\
\hline & Finger millet & 17.0 & $<0.020$ \\
\hline & Simsim & 8.0 & $<0.020$ \\
\hline \multirow[t]{3}{*}{ Tubers/roots } & Cassava & 134.0 & 0.036 \\
\hline & Sweet potatoes & 163.0 & 0.023 \\
\hline & Yams & 41.2 & 0.054 \\
\hline \multirow[t]{3}{*}{ Legumes/nuts } & Bambala nuts & 12.0 & $<0.020$ \\
\hline & Groundnuts & 7.0 & $<0.020$ \\
\hline & Beans & 34.0 & 0.022 \\
\hline \multirow[t]{7}{*}{ Fish } & Sardine & 176.0 & $<0.020$ \\
\hline & Catfish & 69.0 & 0.335 \\
\hline & Nile perch & 65.0 & 0.370 \\
\hline & Lungfish & 54.0 & 0.245 \\
\hline & Furu & 23.5 & $<0.020$ \\
\hline & Soga & 34.0 & $<0.020$ \\
\hline & Tilapia & 260.0 & 0.123 \\
\hline \multirow[t]{5}{*}{ Beverage } & Gongo (local spirit) & 10.0 & $<0.020$ \\
\hline & Lubisi (local brew) & 5.0 & $<0.020$ \\
\hline & Kangara (local brew) & 37.0 & 0.020 \\
\hline & Western beer & 18.0 & $<0.020$ \\
\hline & Milk & 0.8 & $<0.020$ \\
\hline \multirow[t]{5}{*}{ Fruits } & Sugarcane & 3.0 & 0.068 \\
\hline & Pawpaw & 4.0 & $<0.020$ \\
\hline & Mangoes & 4.0 & $<0.020$ \\
\hline & Banana & 7.0 & $<0.020$ \\
\hline & Pineapples & 1.2 & $<0.020$ \\
\hline \multirow[t]{3}{*}{ Meat } & Beef & 30.0 & $<0.020$ \\
\hline & Chicken & 23.0 & $<0.020$ \\
\hline & Mutton & 18.0 & $<0.020$ \\
\hline \multirow[t]{3}{*}{ Vegetables } & Tomato & 21.0 & $<0.020$ \\
\hline & Cabbage & 19.0 & 0.123 \\
\hline & Amaranths & 17.0 & $<0.020$ \\
\hline \multirow[t]{2}{*}{ Sugar and salt } & Sugar & 34.0 & $<0.020$ \\
\hline & Table salt & 12.0 & $<0.020$ \\
\hline Drinking water & Drinking water & 885.0 & $<0.020$ \\
\hline
\end{tabular}


Table 3. Average ( \pm SD) Hg Concentrations and \% Intakes for Different Food Categories

\begin{tabular}{|c|c|c|c|c|c|}
\hline Group & $\begin{array}{l}\text { Food Intake } \\
\text { (g/day) }\end{array}$ & $\begin{array}{l}\% \text { of Total } \\
\text { Food Intake }\end{array}$ & $\begin{array}{l}\text { Hg Concentration } \\
\text { ( } \mu \text { g/g wet weight) }\end{array}$ & $\begin{array}{l}\text { Hg Intake from each Food } \\
\text { Category }(\mu \mathrm{g} / \mathrm{day})\end{array}$ & $\begin{array}{l}\text { \% of Total Hg Intake for } \\
\text { Each Food Category }\end{array}$ \\
\hline Rice & 134 & 8.3 & 0.030 & 4.0 & 9.76 \\
\hline Maize & 270 & 17.0 & 0.022 & 6.0 & 14.63 \\
\hline Cereals & $16 \pm 7.64$ & 0.9 & $<0.020$ & 0.20 & 0.49 \\
\hline Tubers/roots & $113 \pm 63$ & 7.0 & $0.04 \pm 0.02$ & 435.0 & 10.61 \\
\hline Regumes/nuts & $18 \pm 14$ & 1.1 & $<0.020$ & 0.4 & 0.98 \\
\hline Fish & $97 \pm 87$ & 6.0 & $0.16 \pm 0.16$ & 15.6 & 38.05 \\
\hline Beverage & $12 \pm 11$ & 0.7 & $<0.020$ & 0.1 & 0.24 \\
\hline Fruits & $4 \pm 2$ & 0.2 & $0.02 \pm 0.03$ & 0.1 & 0.24 \\
\hline Meat & $24 \pm 6$ & 1.4 & $<0.020$ & 0.25 & 0.61 \\
\hline Vegetables & $19 \pm 2$ & 1.2 & $0.05 \pm 0.06$ & 1.0 & 2.44 \\
\hline Sugar and salt & $23 \pm 16$ & 1.4 & $<0.020$ & 0.2 & 0.49 \\
\hline Drinking water & 885 & 54.8 & $<0.020$ & 8.85 & 21.59 \\
\hline Total & 1615 & 100 & 0.380 & 41.05 & 100 \\
\hline
\end{tabular}

The number of food stuffs mentioned in this study is smaller than that reported in similar studies conducted in Chile (300; [11]) and Japan (116; [12]). This difference can be explained by the poor access to diverse food stuffs in subSaharan Africa. Populations in rural sub Saharan Africa mainly depend on maize, rice and tuber crops [13] as their major sources of carbohydrate. Based on that, this study considered rice, maize, tuber crops and fish as principal food categories for investigation. It is noted that the consumption of fish reported in this study ( $97 \mathrm{~g} /$ day) is higher than one reported in the United Kingdom (21 g/day), Spain (75 g/day), Norway (53 to $80 \mathrm{~g} /$ day), Greece (38 g/day) [14], Canada (22 to $50 \mathrm{~g} /$ day) [15] and Chile (33 g/day) [11] whereas the consumption of meat ( $24 \mathrm{~g} /$ day) is very low in this study compared to values reported in Chile (178 g/day) [11]. These differences in daily consumption of each of the food items should be taken into account when establishing the maximum mercury content in food, as standards used in developed countries may not be suitable for implementation in sub Saharan African countries and especially this region where fish eating is a custom almost discouraging other food stuffs.

The high levels of mercury in Nile perch reflect higher trophic level of this species in Lake Victoria and its carnivorous feeding behaviour [16]. The presence of relatively high $\mathrm{Hg}$ concentrations in cassava $\left(0.036 \mu \mathrm{g} \mathrm{g}^{-1}\right)$, sweet potatoes $\left(0.023 \mu \mathrm{g} \mathrm{g}^{-1}\right)$, sugarcanes $\left(0.068 \mu \mathrm{g} \mathrm{g}^{-1}\right)$, yams $(0.054 \mu \mathrm{g}$ $\left.\mathrm{g}^{-1}\right)$, rice $\left(0.026 \mu \mathrm{g} \mathrm{g}^{-1}\right)$ and cabbages $\left(0.123 \mu \mathrm{g} \mathrm{g}^{-1}\right)$ is probably due to the cultivation of these crops on $\mathrm{Hg}$ contaminated soils. Evidence for this was obtained during the field survey, where yams, cabbage, sugarcane and rice were found growing in swampy areas which are within the drainage areas for the Mugusu mine through Mabubi river. In general food stuff of aquatic origin or those originating close to the lake had higher mercury concentration compared to those less influenced by aquatic environment. It is also indicated that up to $2.3 \mu \mathrm{g} \mathrm{Hg} \mathrm{g}^{-1} \mathrm{dw}$ concentration were measured in sediment collected from the Mabubi river [17] which supports mercury contamination of the area and consequently the biological life. Apart from this trend, it is worth noted that $\mathrm{Hg}$ concentration in fish and other food categories do not exceed the maximum limit of $0.5 \mu \mathrm{g} \mathrm{g}^{-1}$ provided by WHO [5]. More has been provided especially in relation to the ability of tuber crops to concentrate (bioconcentration) metals [18] but of course this is enhanced by the presence of specific metal in the environment under consideration.

The estimated average mercury intake per person in this area is $41.05 \mu \mathrm{g} / \mathrm{day}$, which is much higher than intakes previously reported using similar approaches in Korea (1.16 $\mu \mathrm{g} /$ day) [9]), the UK (4 $\mu \mathrm{g} /$ day) [19]), Chile (5 $\mu \mathrm{g} /$ day) [11], Japan $(9 \mu \mathrm{g} /$ day) [12], China $(10.3 \mu \mathrm{g} /$ day $)$ [20], USA $(1.25$ $\mu \mathrm{g} /$ day) [21] and Lebanon (3.0 $\mu \mathrm{g} /$ day) [22]. This difference is understandably explained by the difference in diet intake among different countries and communities, which is an important factor in determining the mercury intake. This study is a typical example of this difference where it was observed that fish diet contributed most to the mercury intake $(38 \%)$ and the calculated mercury intake from fish is $16 \mu \mathrm{g}$ /day far higher than that reported in Spain $(13.2 \mu \mathrm{g} /$ day), a country which is considered to have a high fish consumption among the developed countries [23]. Although mercury concentration in maize $\left(0.022 \mu \mathrm{g} . \mathrm{g}^{-1} \mathrm{ww}\right)$ was low, it contributed $14 \%$ to the total mercury intake because it is the major staple food in the studied community. Other food categories which are consumed in large quantities and contributed significantly to the total mercury intake are rice and tuber crops (cassava, sweet potatoes and yams). Again this highlights that eating 
behaviour is an important factor in the determination of mercury intake and possible consequences to human. Therefore Levels of contaminants in the environment should always be supported by other observations in order to suffice the interpretation of pollutant effects to human.

The maximum daily mercury intake recommended by $\mathrm{WHO} / \mathrm{FAO}$ for the protection of general public is $49 \mu \mathrm{g} / \mathrm{day}$ for an adult of $68 \mathrm{~kg}$ [8], this value is higher than the estimated mercury intake of residents living in the Mugusu mining village. Based on the findings that prenatal exposure to $\mathrm{MeHg}$ leads to significant effects during infant development, the World Health Organization (WHO) reduced the mercury daily intake safe limit by half, setting it at $15.5 \mu \mathrm{g} /$ day for the protection of developing foetus [8]. This value is already equivalent to the $\mathrm{Hg}$ intake from the fish category observed in this study, assuming that all $\mathrm{Hg}$ quantity in fish is found as methyl-mercury [24], when all food categories included in this study are consumed the WHO limit is exceeded by a factor of 2.6. These results indicate that there is no health risk for adult consumers although children may be at risk.

The presence of elevated mercury levels in tuber crops that are grown around swampy areas near Mugusu mine does, however, indicate that a significant contribution of gold mining activities can be expected. Like many exposure assessment conducted around the world, this study was limited to the adult fraction of the population $[5,19,21]$. Also the daily intakes calculated in the current study may not fully be the representative of the entire community, therefore, the results from this study do provide a first estimate of the $\mathrm{Hg}$ dietary exposure of people residing in artisanal gold mining areas in Tanzania. This study provides an insight of the possible healthy challenges which can be caused by environmental pollution. For communities like Mugusu special protection measures are needed so as to minimize their exposure to mercury contamination. Although these mercury levels are associated to food intake habit, it is important to note that improper mercury handling has aggravated the wide spread of mercury in the environment. The major and viable protection measure over this problem can be suggested to be on the long-term educational programme and controlled use and disposal of mercury.

\section{CONCLUSIONS}

This is the first study to undertake a total diet approach in estimating mercury intake by people living in artisanal gold mining areas in Tanzania. The estimated Hg intake of 41.05 $\mu \mathrm{g} /$ day is more than two times higher than the safe limit for the protection of the developing foetus and young children $(15.5 \mu \mathrm{g} /$ day $)$ and is above the reported $\mathrm{Hg}$ intakes in Korea, the UK, Chile, Japan, China, the USA and Lebanon. It is concluded that health risks exist for people residing in Mugusu gold mining village and probably other artisanal mining settlements in the world. Therefore, mercury intake in artisanal gold mining settlements should be regularly monitored since changes of income and variation of community composition can lead to changes of eating behaviour and thus total diet mercury intake. The Total diet approach highlighted here is therefore an important contribution to explain the health risks to various communities under similar contaminants.

\section{ACKNOWLEDGEMENT}

This research was funded by VICRES. The field assistance provided by Mr. J. Manaku of the Geita district minerals department is highly acknowledged together with the Mugusu village community.

\section{REFERENCES}

[1] J. R. Ikingura, and H. Akagi, "Monitoring of fish and human exposure to mercury due to gold mining in the Lake Victoria goldfields, Tanzania”. Sci. Total Environ., vol. 19, pp. 59-68, 1996.

[2] J. W. A Kondoro, and M. H Makundi, "Heavy metal pollution in Lake Victoria”. Tanz. J. Sci., 24: 9-21. 1998.

[3] LVEMP, "Lake Victoria Environmental Management Project (LVEMP)" Annual Report p 100, 2002.

[4] J. F. Machiwa, "Metals in Nile perch (Lates niloticus) and suspended particulate matter from lake Victoria, Tanzania", J. Environ. Sci. Health, vol. 40, pp. 1809-1822, 2005.

[5] WHO, "Guidelines for the study of dietary intakes of chemical contaminants", WHO offset Publication, No. 87,1985. Available from: http://www.who.int/foodsafety/chem/gems/en/index3.html Accessed on 10 July 2010.

[6] C. Reilly. Ed., Blackwell Science Ltd: Oxford, UK, 2002.

[7] R. Kroes and G. Kozianowski, "Threshold of toxicological concern (TTC) in food safety assessment", Toxicol Lett., vol. 28, pp. 43-56, 2002.

[8] JECFA report. "Joint FAO/WHO Expert Committee on Food Additives report from the sixty-first meeting", Rome, 10-19 June 2003.

[9] H. Lee, Y. Cho, S. Park, S. Kye, B. Kim, T. Hahm, M. Kim, J. Lee and C. Kim, "Dietary exposure of the Korean population to arsenic, cadmium, lead and mercury", J. Food Comp. Anal., vol. 19, pp. 3137, 2006.

[10] B. Govaerts, B. Beck, E. Lecoutre, C. Bailly, P. Vanden Eeckaut, "From monitoring data to regional distributions: a practical methodology applied to water risk assessment", Environmetrics, vol. 16, pp. 109-127, 2005.

[11] O. Muñoz, J. M. Bastias, M. Araya, A. Morales, C. Orellana, R. Rebolledo and D. Velez, "Estimation of the dietary intake of Cadmium, Lead, Mercury and Arsenic by the population of Santiago (Chile) using a Total Diet Study", Food Chem. Toxicol, vol. 43, pp. $1647-1655,2005$.

[12] T. Maitani, "Evaluation of exposure to chemical subsistence through food-exposure to pesticide, heavy metals, dioxins, acrylamide and food additives in Japan", J. Health Sci., vol. 50, pp. 205209, 2004.

[13] J. Kinabo, A. P. Mnkeni, C. N. B Nyaruhucha, J. Msuya and J. Ishengoma, "Feeding frequency and nutrient content of foods commonly consumed in the Iringa and Morogoro regions in Tanzania”, Internat. J. Food Sci. Nutr., vol. 57, pp. 9-17, 2006.

[14] C. Byrd-Bredbenner, P Lagiou and A Trichopoulou, "A comparison of household food availability in 11 countries". J. Hum. Nutr. Dietetics, vol. 13, pp. 197-204, 2000

[15] M. Legrand, P. Arp, C. Ritchie, and H. M. Chan, "Mercury exposure in two coastal communities of the Bay of Fundy, Canada", Environ. Res., vol. 98, pp. 14-21, 2005.

[16] L. M. Campbell, E. H. Robert, and B. W. Sylvester, "Stable isotope analyses of food web structure and fish diet in Napoleon and Winam Gulfs, Lake Victoria, East Africa", J. Gt. Lakes Res., vol. 29, pp. 243-257, 2003.

[17] R. T Chibunda, A.E Pereka and C. Tungaraza, "Ecotoxicity of sediment collected from artisanal gold mining impacted river to Chironomus riparius in Geita district, Tanzania”, J. Phys. Chem. Earth, vol. 33, pp. 738-743, 2008.

[18] Ekeanyanwu C. R, Opia E. E. and Etienajirhevwe O. F. "Trace Metals Distribution in Some Common Tuber Crops and Leafy Vegetables Grown in the Niger Delta Region of Nigeria", Pak. J. Nutr., vol. 9, no. 10: 957-961, 2010.

[19] G. Ysart, P. Miller, H. Crews, P. Robb, M. Baxter, C. de L'Argy, S. Lofthouse, C. Sargent and N. Harrison, "Dietary exposure estimates of 30 elements from the UK total diety study", Food Addit. Contam, vol. 16, pp. 391-403, 1999.

[20] J. S. Chen, and J. Q. Gao, "The Chinese total diet study in 1990. Part I. Chemical contaminants", J. AOAC Internat., vol. 76, pp. 1193-1205, 1993. 
[21] S. K. Egan, S .S. H Tao, J. A. T Pennington and P. M. Bolger, "US food and drug administration's total diet study: intake of nutritional and toxic elements", Food Addit. Contam., vol. 19, pp. 103-125, 2002.

[22] L. Nasreddine, N. Hwalla, O. El Samad, J. C. Leblanc, M. Hamze, Y. Sibiril and D. Parent-Massin, "Dietary exposure to lead, cadmium, mercury and radionuclides of an adult urban population in Lebanon: A total diet study approach", Food Addit. Contam., vol. 23, pp. 579-590, 2006.
[23] Urieta, M. Jalón and I. Equileor, "Food surveillance in the Basque country (Spain) II. Estimation of the dietary intake of organochlorine, pesticides, heavy metals, arsenic, aflatoxin M1, iron, and zinc through the total diet study, 1990/91", Food Addit. Contam, vol. 13, pp. 29-52, 1996.

[24] US EPA, "Water quality criterion for the protection of human health: Methylmercury", Washington, 2001. Available from: www.epa.gov/waterscience/criteria/methylmercury/factsheet.html. Accessed on 11 August 2010.

(C) Tungaraza et al.; Licensee Bentham Open.

This is an open access article licensed under the terms of the Creative Commons Attribution Non-Commercial License (http://creativecommons.org/licenses/by-nc/3.0/g) which permits unrestricted, non-commercial use, distribution and reproduction in any medium, provided the work is properly cited. 